\title{
RELATIONSHIP OF PARENTING TO TEMPER TANTRUM BEHAVIOR OF CHILDREN 3-5 YEARS OLD IN PAUD MAWAR FKIP UNPATTI
}

\author{
Hermelina Abarua \\ Department of Education, Faculty of Teacher Training and Education, \\ Pattimura University Ambon. \\ Email : emiassor@gmail.com
}

\begin{abstract}
The Relationship of Parenting to Temper Tantrum Behavior Children 3-5 Years Old in PAUD Mawar FKIP Unpatti" Department of Education Faculty of Teacher Training and Education Faculty of Pattimura University Ambon. Tantrums (or temper tantrums) are emotional outbursts, usually associated with children or people in emotional distress, which are usually characterized by stubbornness, crying, screaming, screaming, screaming, insubordination, ranting angry, angry, resistance to efforts to calm and, in some cases, violence. Physical control can be lost, the person may not be able to remain silent, and even if the person's "goals" are fulfilled he may remain uneasy. This research was carried out at PAUD Mawar FKIP Unpatti. The purpose of the study was to determine the relationship of parenting to the incidence of temper tantrums in children aged 3-5 years in PAUD Mawar Unpatti. Research using a quantitative approach emphasizes its analysis on numerical data that is processed by statistical methods. The results of the analysis using the Chi Square statistical test with the SPSS program version 16.0 obtained $\rho=0.001<\alpha=0.05$ with a pearson count $=15.069$ then H1 accepted H0 was rejected, which means there is a relationship between parenting parents with temper tantrums in preschool age children (3-5 Years) in Mawar PAUD FKIP Unpatti with a correlation of 0.501 which is interpreted that the strength of the relationship between variables is a moderate level. 31 respondents in PAUD Mawar FKIP Unpatti showed that parenting in the Poor category was 10 respondents (32.46\%) and 21 respondents $(67.74 \%)$ had good parenting. Data of 31 respondents in PAUD Mawar FKIP Unpatti showed 15 respondents $(48.38 \%)$ showed high temper tantrums, 10 respondents $(32.25 \%)$ showed moderate temper tantrums, and 6 respondents $(19.35 \%)$ showed low temper tantrums.
\end{abstract}

Keywords: Parenting, Temper Tantrum, pre-school students

\section{Introduction}

Tantrums (or temper tantrums) are emotional outbursts, usually associated with children or people in emotional distress, which are usually characterized by stubbornness, crying, screaming, screaming, screaming, insubordination, ranting angry, angry, resistance to efforts to calm and, in some cases, violence. Physical control can be lost, the person may not be able to remain silent, and even if the person's "goals" are fulfilled he may remain uneasy.

Tantrums are one of the most common forms of problematic behavior in children but tend to decrease in frequency and intensity as the child grows. In toddlers, tantrums or tantrums can be considered as normal, even as a measure of the strength of character development. (Robin Skynner 1993: 177) While tantrums are sometimes seen as predictors of anti-social behavior in the future, (Potegal: 2003140-147.) In another sense it is merely a sign of excessive frustration that is age-appropriate, and will decrease with time to be treated who is calm and consistent. (Roy Benaroch, Solving Health and Behavioral Problems from Birth Through Preschool (2008) p.157 At this time children already have a basis for the attitude of morality toward social groups (parents, siblings, and peers). Through the experience of interacting with others children learn understand which activities or behaviors are good / may / be accepted / approved or bad / may not Based on

Received October $5^{\text {th }} 2019$, Revision Februrry $5^{\text {th }} 2020$, Accepted for publication February $18^{\text {th }} 2020$.

Copyright (C) 2020 Published by FKIP - Unpatti, ISSN 2721-3110 
his experience, the child must behave at this time (such as washing hands before eating, brushing teeth before going to sleep).

From the preliminary study in PAUD Mawar by asking the teachers in PAUD, There are some students around 10 from the total number of students who find it difficult to like the situation at school. Slow to adapt. According to the assumptions the authors of these children are indicated to experience temper tantrums. For this reason, the authors are interested in conducting research in PAUD Mawar to find out the relationship between parenting parents on the incidence of temper tantrums in preschool age children

\section{a. Temper Tantrums Understanding}

Tantrum temper is a burst of emotions that is explosive and uncontrolled. Tantrum temperatures often occur in children 15 months to 6 years (Zaviera, 2008). Generally young children are more emotional than adults because at this age children are still relatively young and cannot control their emotions. At the age of 2-4 years, the emotional characteristics of children appear on the temper tantrum or temper tantrum (Hurlock, 2000). Attitudes are shown to display displeasure, children do excessive actions, such as crying, screaming, throwing objects, rolling around, hitting his mother or other major activities (Hurlock, 2000). Tantrums occur more easily in children who are considered difficult with the characteristics of having the habit of sleeping, eating and irregular bowel movements, difficult to like the situation, food and new people, slow to adapt to changes, more often negative moods, easily provoked, easy to feel angry and difficult to distract (Zaviera, 2008).

La Forge (in Zaviera, 2008) considers that tantrum is a behavior that is still classified as normal which is part of the development process, a period of physical, cognitive, and emotional development. As a period of development, tantrums will definitely end. Based on the theories above, it is concluded that temper tantrums are explosive bursts of emotions due to the unpleasant atmosphere felt by children. The emotional outburst can be crying, screaming, throwing things, rolling around, hitting his mother or other big activities2. Tantrum manifestations based on age group. Based on tantrum age groups can be divided into (Zaviera, 2008): a. Under 3 years old, when children under 3 years old, the form of tantrums is crying, biting, hitting, kicking, screaming, squealing, arching his back, throwing his body to the floor, banging hands, holding his breath, banging his head and throwing things (Zaviera, 2008) .b. 3-4 years old. Children with an age range of 3 years to 4 years form tantrums including behavior in children under 3 years old plus stomping, screaming, punching, slamming doors, criticizing and whining (Zaviera, 2008). c. Age 5 years and above, the form of tantrums in children aged 5 years and over is increasingly widespread which includes the first and second behavior coupled with cursing, swearing, hitting, self-criticizing, breaking objects intentionally and threatening (Zaviera, 2008). According to Purnamasari ( 2005) mentions that every child who is at least 18 months to three years old and even more will defy orders and show their individuality at a time. This is a normal part of toddlers because they continuously explore and learn the boundaries around them. Children will show a variety of behaviors, such as stubbornness and defiance because they are developing their personality and autonomy. Tantrums are also a normal way to release all the feelings that accumulate. A child at this age will exhibit some or all of the following behaviors: a. Denial of control in any form. b. The desire to be independent, more demanding and show disobedient behavior. c. Switching between independence and acting spoiled. d. Want to get control and want to control.e. Generally shows tantrums.

\section{b. Factors that cause temper tantrums}

There are several factors that cause temper tantrums, including (Zaviera, 2008):

Received October $5^{\text {th }} 2019$, Revision Februrry $5^{\text {th }} 2020$, Accepted for publication February $18^{\text {th }} 2020$.

Copyright (C) 2020 Published by FKIP - Unpatti, ISSN 2721-3110 
a) Obstruction of children's desire to get something. Children if they want something must always be fulfilled, if they do not succeed in fulfilling these desires then it is very possible for children to use tantrums to pressure parents to get what they want (Zaviera, 2008).

b) Inability of children to express themselves. Children have language limitations, when he wants to express something but cannot, and parents cannot understand, this can trigger children to become frustrated and expressed in the form of tantrums (Zaviera, 2008).

c) Unfulfilled needs. An active child needs enough space and time to move around and cannot stay still for a long time. If at any time the child must take a long trip by car, then the child will feel stressed. One example of stress relief is tantrums (Zaviera, 2008).

\section{c. Theoretical framework}

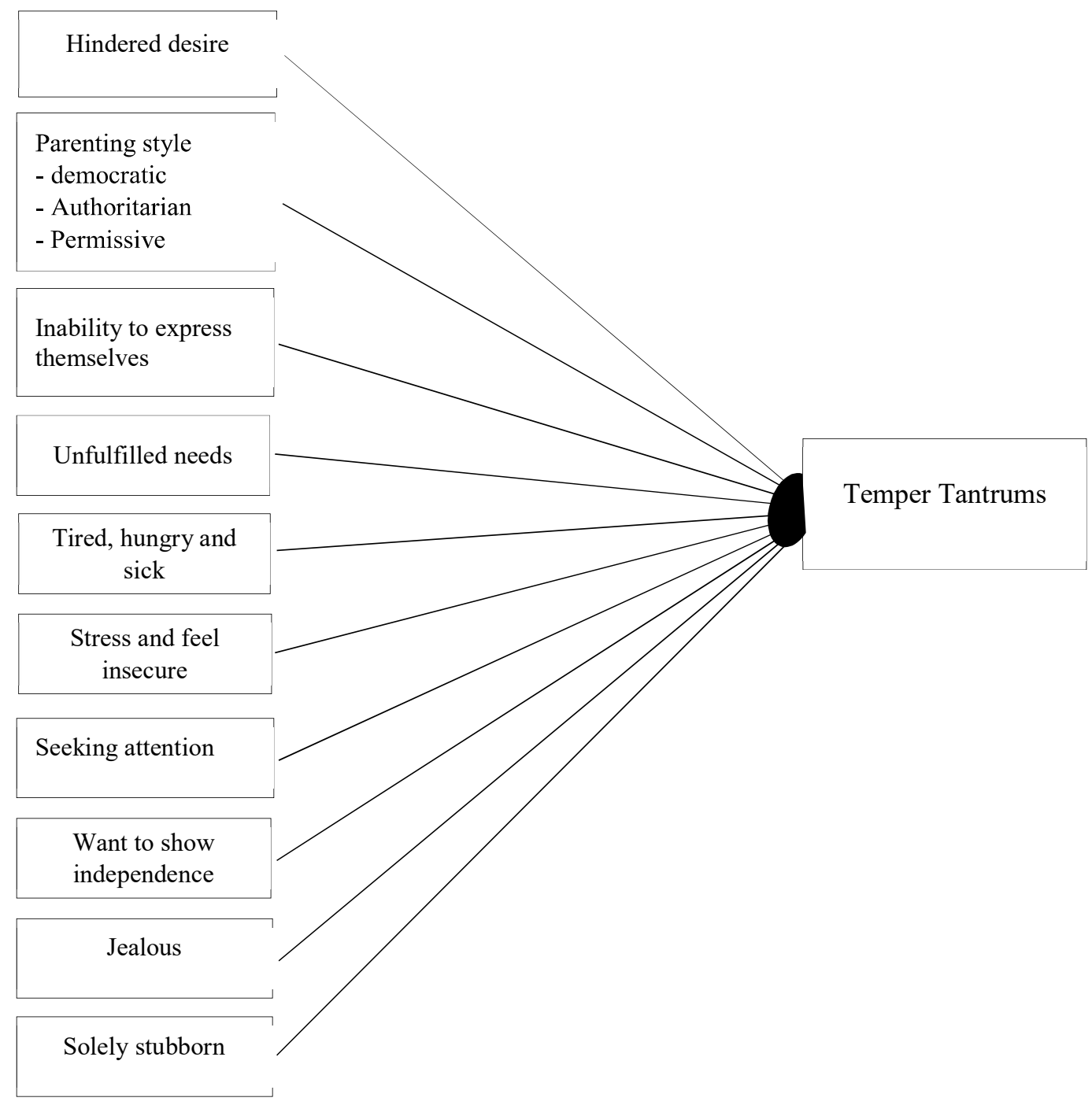

Figure 1. Theoretical Framework (Sources: Zaviera, 2008, Drey, 2006) 


\section{c. Parenting style.}

The way parents take care of children also has a role to cause tantrums. Children who are too spoiled and always get what they want, can stun when a request is rejected. Children who are too spoiled and always get what they want, can stun when a request is rejected. For children who are too and dominated by their parents, at times children may react against the dominance of parents with tantrum behavior. Parents who care for children inconsistently can also cause tantrums (Zaviera, 2008).

The pattern of parenting in this case is actually more on how parents can provide examples or examples to children in every behavior because children will always imitate every parent's behavior. If the child sees a parent venting anger or shouting frustration because of something small, then the child will have difficulty controlling themselves. A child needs to see that adults can overcome frustration and disappointment without having to lose control, so the child can learn to control themselves. Parents do not expose children to show a calm attitude if they always set a bad example. e. Children feel tired, hungry or in a state of pain, the condition of pain, fatigue and hunger can cause children to be fussy. Children who are not good at expressing what is felt then the tendency that arises is fussing, crying and acting aggressively (Zaviera, 2008). f. Children are stressed and feel insecure, Children who feel threatened, uncomfortable and stressed especially if they cannot solve their own problems plus the environment that does not support triggers the child to become temper tantrum (Zaviera, 2008).

Tantrum triggers according to Purnamasari (2005) states that: a. seeking attention Although tantrums are rarely done just to manipulate parents, if the result of tantrums is the full attention of an adult, this gives a reason to start showing tantrums. Asking for something that he could not have, the child insists on wanting ice cream for breakfast or asks his mother to hold him while preparing food. Want to show independence Children want to wear clothes that are less appropriate to the weather that day, such as T-shirts on cold days, or do not want to eat food that has been prepared, frustration with limited ability to do the activities he tried, children want to show their ability to do some things themselves, such as dressing, or finding pieces of puzzle, but cannot succeed in completing it, Jealousy, Usually shown to brother, sister or other. He wants their toys or books, Challenging authority, Children suddenly don't want to do routines like bedtime routines, or refuse to go to daycare, even though he is always happy there, Solely stubborn A child can just show any tantrums what happens to parenting is how parents take care of children also play a role to cause tantrums. Children who are too spoiled and always get what they want, can stun when a request is rejected. Children who are too spoiled and always get what they want, can stun when a request is rejected. For children who are too and dominated by their parents, at times children may react against the dominance of parents with tantrum behavior. Parents who care for children inconsistently can also cause tantrums (Zaviera, 2008). The pattern of parenting in this case is actually more on how parents can provide examples or examples to children in every behavior because children will always imitate every parent's behavior. If the child sees a parent venting anger or shouting frustration because of something small, then the child will have difficulty controlling themselves. A child needs to see that adults can overcome frustration and disappointment without must be out of control, so the child can learn to control themselves. Parents do not expose children to show a calm attitude if they always set a bad example. Children feel tired, hungry or in a state of pain, the condition of pain, fatigue and hunger can cause children to be fussy. Children who are not good at expressing what is felt then the tendency that arises is fussing, crying and acting aggressively (Zaviera, 2008). (F). Children are stressed and feel insecure, Children who feel threatened, uncomfortable and stressed especially if they cannot solve their own problems plus the environment that does not support triggers the child to become temper tantrum (Zaviera, 2008). Tantrum triggers according to Purnamasari (2005) states that: Looking for attention.

Received October $5^{\text {th }} 2019$, Revision Februrry $5^{\text {th }} 2020$, Accepted for publication February $18^{\text {th }} 2020$.

Copyright (C) 2020 Published by FKIP - Unpatti, ISSN 2721-3110 
Although tantrums are rarely done just to manipulate parents, if the result of tantrums is the full attention of an adult, this gives a reason to start showing tantrums. Parental care is the way parents take care of children also has a role to cause tantrums. Children who are too spoiled and always get what they want, can stun when a request is rejected. Children who are too spoiled and always get what they want, can stun when a request is rejected. For children who are too and dominated by their parents, at times children may react against the dominance of parents with tantrum behavior. Parents who care for children inconsistently can also cause tantrums (Zaviera, 2008). The pattern of parenting in this case is actually more on how parents can provide examples or examples to children in every behavior because children will always imitate every parent's behavior. If the child sees a parent venting anger or shouting frustration because of something small, then the child will have difficulty controlling themselves. A child needs to see that adults can overcome frustration and disappointment without having to lose control, so the child can learn to control themselves. Parents do not expose children to show a calm attitude if they always set a bad example.

Children feel tired, hungry or in a state of pain, the condition of pain, fatigue and hunger can cause children to be fussy. Children who are not good at expressing what is felt then the tendency that arises is fussing, crying and acting aggressively (Zaviera, 2008) .f. Children are stressed and feel insecure Children who feel threatened, uncomfortable and stressed, especially if they cannot solve their own problems plus the environment that does not support the child triggers a temper tantrum (Zaviera, 2008).

Tantrum triggers according to Purnamasari (2005) states that: Looking for attention. Although tantrums are rarely done just to manipulate parents, if the results of tantrums are the full attention of an adult, this gives a reason to start showing tantrums.

\section{Methods}

\section{Data Analysis Techniques}

Analysis will be carried out in SPSS 16.0 for Windows. Statistical analysis is carried out on two variables that are suspected to be related or related (Notoatmodjo, 2012). Statistical analysis is the analysis carried out to determine whether there is a relationship between independent and bound variables using statistical tests.

In this study a statistical analysis was conducted to determine the relationship between parenting parents with temper tantrums in preschool children. Because the data in this study are all on a nominal scale, the statistical test used is the Chi Square Table $2 \times 3$ test with a significance level of 0.05 with the formula

$$
\begin{aligned}
& x^{\wedge} 2=\left(\sum(f o-f h)\right) / \text { fh } \\
& \text { Information: } \\
& x^{\wedge} 2=\text { Chi squared } \\
& \text { fo }=\text { Frequency observed } \\
& \text { fh }=\text { Expected frequency (Arikunto, 2011) }
\end{aligned}
$$

In this study using the chi square test with a $2 \times 3$ table with the example table as follows:

Table 1. Table $2 \times 3$ chi square

\begin{tabular}{|l|c|c|c|c|}
\hline \multirow{2}{*}{ Parenting } & \multicolumn{3}{|c|}{ Tamper Tantrum } & \multirow{2}{*}{ Total } \\
\cline { 2 - 4 } & Light & Medium & High & \\
\hline Both & A & B & C & A+B+C \\
\hline Not Good & D & E & F & D+E+F \\
\hline Total & A + D & B + E & C $+F$ & A+B + C D $+E+F$ \\
\hline
\end{tabular}


The frequency of observations (fo) is the result of observations made further to test the hypotheses that have been set at the error level of $5 \%$ based on the calculations above, conclusions can be drawn.

Reject H0 (accept Ha, if a count is obtained $>$ table or $\mathrm{p}$ value $0,0 \alpha(0.05)$

Receive H0 (reject Ha), if a count is obtained $<$ table or $\mathrm{p}$ value $>\alpha(0.05)$

To determine the closeness of the relationship between variables with nominal data that is the coefficient of association contingency coefficient (C) with a formula that contains the value of chi squared. To find out the close relationship between the two variables can be searched using the contingency coefficient (KK).

\section{Information :}

$\mathrm{KK}=$ Contingency Coefficient

$\mathrm{X} 2=$ Chi Square

$\mathrm{N}=$ Number of Samples (Arikunto, 2011)

The relationship between the two variables is more closely the price of KK ranges from $0-1,000$. From the results of calculations to interpret how strong the relationship in words as follows (Sugiyono, 2011).

1. 0.00-0.199 Very low

2. 0.20-0.399 Low

3. 0.40-0.666 Medium

4. 0.60-0.799 Strong

5. $0.8-1,000$ Very strong

\section{Result and Discussion}

This research was carried out at PAUD Mawar FKIP Unpatti. The purpose of the study was to determine the relationship of parenting parents to the incidence of temper tantrums in children aged 3-5 years in PAUD Mawar Unpatti. Research using a quantitative approach emphasizes its analysis on numerical data that is processed by statistical methods.

The results of the analysis using the Chi Square statistical test with the SPSS program version 16.0 obtained $\rho=0.001<\alpha=0.05$ with a pearson count $=15.069$ then $\mathrm{H} 1$ accepted $\mathrm{H} 0$ was rejected, which means there is a relationship between parenting parents with temper tantrums in preschool age children (3-5 Years) in Mawar PAUD FKIP Unpatti with a correlation of 0.501 which is interpreted that the strength of the relationship between variables is at a moderate level. 31 respondents in PAUD Mawar FKIP Unpatti showed that parenting in the Poor category was 10 respondents (32.46\%) and 21 respondents $(67.74 \%)$ had good parenting. Data of 31 respondents in PAUD Mawar FKIP Unpatti showed 15 respondents $(48.38 \%)$ showed high temper tantrums, 10 respondents $(32.25 \%)$ showed moderate temper tantrums, and 6 respondents (19.35\%) showed low temper tantrums.

Received October $5^{\text {th }} 2019$, Revision Februrry $5^{\text {th }} 2020$, Accepted for publication February $18^{\text {th }} 2020$.

Copyright (C) 2020 Published by FKIP - Unpatti, ISSN 2721-3110 


\section{References}

Arikunto 2011. Research Procedure A Practical Approach. Jakarta: Rineka Cipta. Aziz 2008. Introduction to Children's Health Sciences. Jakarta: Salemba Medika. Azwar, Saifuddin. 2010. Research Methodology. Yogyakarta: Learning Library. Balitbang RI Ministry of Health. 2013. Basic Health Research. Jakarta: Balitbang Kemenkes.

Chaplin, J. P. 2009. Complete Dictionary of Psychology. Jakarta: Rajawali Press.

Dariyo, Agoes. 2007. Child Development Psychology First Three Years. Bandung: Refika Aditama.

Listiana, Esti.2015. Difference in Risk of Tantrum Temper in Preschool Children between Unworked and Working Mothers in RA MAN Gebang, Patran Urban Village. Scription. University of Jember. http://repository.unej.ac.id/ [Accessed February 20, 2017]

Gunarsa, Singgih D. 2008. Child and Adolescent Psychology. Jakarta: PT BPK Gunung Mulia.

Hagan, Jessica S. 2006. Educating Children Entering Preschool Age. Jakarta: PT. Pustakaraya's achievements.

Hames, Penney. , 2005. Facing and Overcoming a Child who Like to Run Away. Jakarta: PT Gramedia.

Hasan, Maimunah. 2011. Early Childhood Education. Jogjakarta: Diva Press.

Hayes, Eileen. 2007. Tantrums. Jakarta: Erlangga.

Hockenberry, M. J Wilson, D. 2013. Wong's essential pediatric nursing. St. Louis: Mosby Elseiver.

Hurlock, E.B. 2010. Developmental Psychology An Approach Throughout the Life Span. Jakarta: Erlangga.

International Save The Children Alliance. 2005. Child right programming. Sweden: National Library.

Ismaya, Y. 2010. Effect of Timeout Use on Tantrum Temperature Decrease in Toddler Age. Journal entry. Pekanbaru: PSIK UR.

James, S.R \& Ashwill, J. W. 2007. Nursing care of children: principles \& practices.St. Louis: Elseiver Saunders.

John W, Santrock. 2013. Child Development. Jakarta: Erlangga.

Kartono, Kartini. 1991. Guidance for Children and Children with Problems. Jakarta: CV. Rajawali.

Big Indonesian Dictionary, Fourth Edition. 2008. Jakarta: Gramedia Main Library.

Nursalam. 2013. The concept and application of ipenelititan methodology in nursing. Jakarta: Salemba Medika.

Notoatmodjo. 2010. Health Research Methodology. Jakarta: PT. Rineka Cipta

Onder A, Gulay H. 2009. Reliability and validity of parenting style \& dimension questionnaire. Procedia Social Behavioral Science.

Robinson, C., Mandleco, B., Olsen, S. F., \& Hart, C. H. (1995). Authoritative, authoritarian, and permissive parenting practices: Development of a new measure. Psychological Reports, 77, 819-830.

Salkind, Neil J. 2002. Child Development. USA: Macmillan Reference.

Sekar Rizkia, Kirana. 2013. Relationship of parenting parents with the temper tantrums of preschool children. Description of the Faculty of Education, Department of Psychology, UNS

Setiadi. 2013. Concepts and Practices of Nursing Research Writing. Yogyakarta: Graha Science.

Received October $5^{\text {th }} 2019$, Revision Februrry $5^{\text {th }} 2020$, Accepted for publication February $18^{\text {th }} 2020$.

Copyright (C) 2020 Published by FKIP - Unpatti, ISSN 2721-3110 
Soetjiningsih, Christiana Hari. 2012. Child Development. Jakarta: Prenada Media Group. Syam Subhan 2013. Relationship of Parenting Patterns to the Occurrence of Tantrum Temper Toodler Children in PAUD Dewi Kunti Surabaya.

Syaidze, 2016. https://brainly.co.id/tugas/5108994 Accessed April 16, 2017 at 6.14 WIB. Sugiyono 2011. Qualitative, quantitative research methods. Bandung: Alfabeta

Saifuddin Azwar. 2012. Preparation of Psychology Scale, Issue 2. Yogyakarta: Student Library.

Wakschlag, Lauren S., Choi, Seung W., Carter, Alice S. 2012. Defining the developmental parameters of temper loss in early childhood: implication for developmental psychopathology. The Journal of Child Psychology and Psychiatry (Vol. 53, No.11, November 2012).

Tandry, N 2008. Bad behavior, tantrums and tempers. Jakarta: PT. Elex Komputindo.

Zaviera, F 2008. Recognizing and understanding child development. Jogjakarta: Heart Word 